To cite this article / Para citar este artículo:

O'Hagan, Angela. "Introduction. "A critical practice of thinking otherwise": Bacchi, gender and public policy analysis». En Feminismo/s, 35 (junio 2020): 13-28. Monographic dossier / Dossier monográfico: A critical practice of thinking otherwise: Bacchi, Gender and Public Policy Analysis, coord. Angela O'Hagan, DOI: 10.14198/fem.2020.35.01

\title{
INTRODUCTION. «A CRITICAL PRACTICE OF THINKING OTHERWISE»: BACCHI, GENDER AND PUBLIC POLICY ANALYSIS
}

\author{
INTRODUCCIÓN. «UNA PRÁCTICA CRÍTICA DE PENSAR \\ DE OTRA MANERA»: BACCHI Y EL ANÁLISIS DE GÉNERO \\ EN LA POLÍTICA PÚBLICA
}

\author{
Angela O'HAGAN \\ Glasgow Caledonian University \\ Angela.OHagan@gcu.ac.uk \\ https://orcid.org/0000-0002-6130-8186
}

Keywords: Gender analysis; Public policy; Inequality; Feminism; Human rights.

Palabras clave: análisis de género; política pública; desigualdad; feminismo; derechos humanos.

All too often the question «what's gender got to do with it?» still arises with government officials, policy actors, elected politicians and of course in everyday conversations. As long as these formal actors -policy makers and politicians- continue to contain thinking and consideration of gender equality in the policy making process to more superficial notions of equality of opportunity and equal treatment, the dimensions of gendered relations and the complex interactions across policy domains will remain invisible and policy making, and the silences of assumed norms that shape policy «representations» will remain. If gender equality is considered to be a matter of 
«women's policy» or a secondary component of labour market and employability, or childcare, or social security and health policy, for example, then the structural constraints of gendered norms and relations will not be addressed or the transformational potential of gender equality realised.

In Bacchi's 'What's the Problem Represented to be?' (WPR) approach, she offers an analytical strategy to reveal the politics inside policy making. Bacchi and Goodwin (13-26) propose using the WPR approach to «make politics visible», by exploring how governmental practices produce «problems» and particular kinds of problems. By seeking to reveal the assumptions and ascribed meanings and interpretations, Bacchi is encouraging critical engagement with what information, knowledge, and assumptions have led to the «representation» of a policy "problem» in a particular way.

In presenting Bacchi's «What's the Problem Represented to be?» (WPR) framework as the «critical practice of thinking otherwise», Bacchi and Goodwin capture the essence at the core of critical feminist policy analysis. This is the framing approach of this special issue of Feminismos. The aspiration of the authors -with an encouraging representation of Early Career Researchers among more established scholars- is to explore a series of public policy domains and topical «problems» using Bacchi's framework. Across the articles, the authors explore how gendered dimensions and gender equality objectives have informed or have been absent in the representation of the policies in focus, and in the teaching and learning of public and social policy students. The authors discuss how gendered knowledge continues to be treated as a secondary consideration, subjugated in the policy process. As a collective endeavour, this special issue engages in how gendered knowledge is deliberately developed and nurtured in policymaking institutions or is deliberately silenced or wilfully ignored.

Gender analysis continues to be a blind spot in public policy making. The absence of, or failure to access and utilise, gender data is problematic. Even more so is the ongoing lack of intersectional data that reveals the experience of individuals in relation to how their gender, race, class and potentially disability combine. That gender analysis is not an integrated or regularised part of policy making across policy domains means that the gendered dimensions of use of time and space in relation the access to and use of public services such as transport, health, education, public space, culture and sports facilities, 
and so on are silenced and rendered invisible. This means there is a lack of understanding of the «lived effects» (Bacchi 16-18; Bacchi and Goodwin 2) of gender norms that structure and constrain the social, economic and political opportunities and experiences of women and men, most usually to the detriment of women.

Bacchi's elaboration of the three types of effects of policy as discursive, subjugation, and lived effects are based on a Foucauldian analysis of «dividing practices» which function to separate groups of people from one another and which can also produce «governable subjects» (Bacchi and Goodwin 2). In this way, women can be separated out as a distinct problem to be dealt with separately from the «real» problem at hand -labour market participation rates, tax revenue, deficit reduction, or whatever the "problem» is that government is seeking to address. It was this problematizing of women, rather than the societal and institutional structures, resulting in the creation and sustained effects of gendered norms and relations that gender mainstreaming as a meta-analysis in the public policy process was intended to address. Furthermore, feminist institutionalism has sought to spotlight and challenge the analysis of institutional practice by exposing androcentric bias with the structures, staffing, and processes of policy institutions.

Over the years Bacchi and colleagues have urged some caution around the notion and implementation of gender mainstreaming with the repeated caveat of «What are we mainstreaming when we mainstream gender?» (Bacchi and Eveline, Mainstreamng-WPR). In Bacchi's construction of how policy «problems» are made, she argues that we should think about policies as «productive» or «constitutive». Drawing on her original framework, Bacchi explains this idea as

policies and policy proposals give shape and meaning to the 'problems' they purport to 'address'... policy 'problems' do not exist 'out there' in society, waiting to be 'solved' through timely and perspicacious policy interventions. Rather, specific policy proposals 'imagine' 'problems' in particular ways that have real and meaningful effects (111).

Bacchi and Eveline go on to build on previous proposition from Bacchi that «policies do not simply 'deal with' the 'problem' of 'gender inequality'. Rather, policies create different impressions of what the 'problem' of 'gender equality' entails.» (112) Therefore, how 'gender' is understood and what meanings are 
attached to the term 'gender equality' require to be unpacked, and the WPR approach helps us do that. In understanding policy decisions and propositions, if we can understand how they have been constituted - as what kind of problem (fiscal, social, structural) and about how 'who' the policy is 'for' or will effect was constructed, we can begin to work backwards, revealing the norms and assumptions that shaped the policy decision. Bacchi, and Bacchi and Eveline (Mainstreaming-WPR) have described that how policies are represented can reinforce categories of people, including «women» and «men», and can reproduce certain understandings discursively and therefore in terms of lived effects. This is their idea of gendering, that policies can reinforce social relations, producing and reinforcing «specific categories of social being and specific patterns of social organisation», and that these categories are, or should be, acknowledged and explored as political categories of identity (112).

In this special issue, the articles by Teasdale, and Cohen and Samzelius engage with the notion of gendering. They highlight how policies in relation to care, reconciliation of work and caring, and the specific categorising of lone parents who are predominantly women are constituted and framed in ways that reinforce expectations around established gendered norms and the role of women primarily as carers and secondarily as economically independent. Yet, as Cohen and Samzelius illustrate, in «problem representation» of social security support for lone parents, women's lack of economic independence and perceived reliance on the state, due to their parental and caring status, is to be castigated rather than the state having a role in the welfare and wellbeing of its population. The gendering of this «problem» takes its form from the persistent subjugation of women, socially and economically, rather than a progressive intent to liberate women from established roles, and recast gender relations to the benefit of women and men.

Wylie's interviews with women and men chefs in restaurant kitchens reinforces the prevalence of gendered thinking and the gendering of women's participation in a professional environment. In Wylie's interviews, her contributors break the «silences» that persist and continue to reinforce established categorisations and assumptions. Furthermore, the assumptions and knowledges on display a wilful ignorance from the male managers in relation to women's position and to the sustainability agenda also in focus. The entrenched, and 
even hostile resistances to addressing the structural constraints resonates with findings from studies of other occupational environments, such as the study of engineering workplaces in Australia by Franzway et al. Wylie points to the need for systemic change to gendered norms and attitudes to environmental sustainability practices and that the necessary macro-level policy and microlevel attitudinal changes are intertwined. This resonates with the calls from Franzway et al. for a focus on context and culture of policy and practice, rather than problematizing individual women (93).

In the contributions from Wilson and Campbell, Steinpórsdóttir and Einarsdóttir, we can see the silences in operation among bureaucrats who require direction from within the administration in order to action measures to unblock gendered barriers to services or regard the process of unpacking what's behind the problem as someone else's job, rather than integral to public policy design and implementation. Therefore, when gender mainstreaming is presented politically as a gender equality policy, Bacchi and Bacchi and Eveline are right to urge caution. As the contributors in this special issue highlight, unless there is a level of gendered knowledge, that reveals and recognises the discursive and lived effects of the categorisations of gendered roles and expectations, and a political engagement or will to intervene to transform these realities, then mainstreaming gender may just continue to mainstream gendering and the persistent inequalities that follow from that.

In Bacchi and colleagues' exploration of the types of effects of policy, they encourage analysis of the discursive effects that show how the «terms of reference established by a particular problem representation set limits on what can be thought and said» (Bacchi and Goodwin 2). Subjectification effects draw attention to how «subjects» are implicated in problem representations, how they are produced as specific kinds of subjects. Mukhopadhyay, also draws on Foucault's concept of «governamentality», that is «the way governments try to produce the citizen best suited to fulfil its policies and as well to the organised practices through which subjects are governed» (2). In her critique of gender mainstreaming in development policy and institutions, Mukhopadhyay focuses on «the dominant set of practices and technologies of power that have structured and shaped the process and framed our practice» (2). 
It is this dominance and the prevalence of established practices, which Bacchi and Goodwin claim produces «identified problem representations» (22). Feminist institutionalist and feminist economics analysis has exposed the androcentric bias of government institutions and the economic and political models they pursue. Insights from multiple feminist theories reveal both the «differential power relations» and the way in which different «knowledges» operate, resulting in some being «subjugated» (22). In practice, this means a disregard -intentional or otherwise- for ensuring gendered knowledge, based on an understanding of the lived effects of discrimination, subordination and inequality on the basis of gender and its intersections with race, class and disability, is the norm. The failure to generate, access and utilise gender disaggregated data as a matter of course is part of this persistent «problem»: the problem of «gender blind» policy making (Eveline and Bacchi) which in turn is not regarded as a problem in mainstream policy making because «what's gender got to do with it...?». So long as the gendered dimensions of economic relationships at the individual and household levels or with the state; or the gendered patterns of time use directed by the division of unpaid care work, which intersect with women and men's economic positions, use of public space and services, and access to political participation do not inform «problem representation» then gender equality will not be advanced through mainstream public policy at any transformative pace.

Bacchi's advocacy for understanding the «lived effects» of public policy decisions is a direction for policy makers -inside and outside governmentto make themselves aware of how the effects of policy decisions, based on identified problems representations, «translate into people's lives». It is a call for policy making that «encourage[s] a critical practice of thinking otherwise» (Bacchi and Goodwin 22). This means identifying and calling attention to the «silences» or «unproblematized» elements within what a problem is represented to be (Bacchi). For example, the «problem» of women's lower labour market participation rates or the occupational segregation and persistent gender pay gaps therein, are not a consequence of choice but rather the combined effects of gendered norms and expectations, and the undervaluing -conceptually and financially- of «women's work».

The absence of gender analysis is present across all policy domains -to greater and lesser degrees- and characterises all aspects of mainstream policy 
processes, from ideas generation through to implementation and evaluation. In calling for a re-gendering of public policy, María Bustelo (2) points to the worrying reality of the «evaporation» or fading away of gender from public policy, particularly by the evaluation stage of a policy, programme or project to assess what the outcomes or changes might have been. This further disregard and lack of policy interest in whether the status quo has changed and to whose benefit or detriment reinforces the lesser value attributed to gender equality, and other forms of inequality, in what is still regarded as «mainstream» policy. In this way, gender equality continues to be reserved as a marginal or «specialist» interest area of policy analysis and political science.

Since the mid 1990's proclamations by supranational institutions such as the United Nations, the Commission of the European Union, and the Council of Europe, heralded the arrival of «gender mainstreaming». This meta-analysis as an approach to policy making, rather than a gender equality policy in itself, intended to shift the onus from feminist advocates and the slow process of legal reform and extension of rights and protections, and to implicate institutions in the process of integrating an informed gender-awareness at all stages of policy making. This was an important shift, intending to make policy and institutions of government responsible for enacting transformational gender policy. Furthermore, among the original aspirations of gender mainstreaming was the ambition to open up the policy process to more democratic participation as well as transparency in the policy process. As the contributions in this special issue reflect, gender mainstreaming has not secured the desired results in terms of its transformative approach to equality and to policy making. The articles by Wilson and Campbell; Wylie; Steinpórsdóttir and Einarsdóttir particularly highlight this, along with the perspective from Teasdale, all of which expose the additive approach to gender and policy making. That is, where gender is seen as an additional rather than an integral component of policy analysis and formulation. How far have we come then from the what Bunch coined as the «add women and stir» approach that gender mainstreaming was to move us on from? The authors in this special issue present evidence of the absence of the «lived effects» of gender inequality as «analytical category» (Bacchi and Goodwin 2) and the evaporation of gender analysis and focus, even when expressed institutional 
commitments to gender mainstreaming or gender budgeting and legal imperatives to integrate gender in policy and practice are in place.

Gender budgeting has been gaining traction, particularly at regional or autonomous, and municipal level globally for over thirty years. As another example of an approach to decision-making in public policy and resource management, gender budgeting has the potential to «activate» gender mainstreaming by bringing in decisions on public finance -how it is raised and spent- into a whole systems approach to integrating gender analysis (O'Hagan 29). As Ozonas reveals in this issue, multiple theoretical perspectives, even those conceived from a human rights and Capabilities Approach perspective, can continue to marginalise a gender perspective, relegating gender equality as a secondary dimension of wellbeing, unless the project is explicitly framed as a gender equality exercise such as the emerging concept and practice of Wellbeing Gender Budgeting. This analysis of Gender Responsive Budgeting (GRB) and Wellbeing Budgeting (WB) is an original contribution in its use of the Bacchi WPR framework and empirically in its comparative case analysis of innovations in public budgets in Bhutan and New Zealand.

In relation to Wylie's research on gendered dimensions of professional kitchen practices, her evidence and analysis speak directly to Bacchi and Goodwin's assertions that «different power relations result in different discursive practices that can create forms of authority for certain knowledge» (22). Wylie offers an original insight into gender relations in a professional environment in the context of environmentally sustainable practices in restaurants. In an innovative combining of gender policy analysis using Bacchi's WPR framework, Wylie spotlights the limitations to integrating gender into «mainstream» policy of environment and sustainability, and business/employment practice. She highlights the missed intersections of both gender awareness and sustainability in organisational practice. In an ambitious analysis, Wylie distils the macro global policy agenda through policy commitments at sub-national government level, into the micro operational setting of professional kitchens where entrenched discriminatory behaviours persist unchecked. The progressive narrative of environmental policy, or business pledges for «Fair Work» in Scotland are insufficient stimuli to transform embedded practices and attitudes where gender equality is still considered not to be integral to everyday business practice. 
Cohen and Samzelius take on a completely different policy arena and point us to the even more damaging «lived effects» of a deliberately gender blind approach to policy in relation to lone parents, the majority of whom are women. In their comparative analysis of the treatment of women lone parents in Sweden and the UK. they reveal a disregard for everyday realities as experienced by women lone parents and the amplification of those everyday discriminations on the grounds of gender, race and ethnicity, and migration status. This article exposes the deficiencies in the Swedish approach, pulling back a curtain on the perceptions of the advanced and integrated nature of gender equality in this Nordic state. Cohen and Samzelius do not use the Bacchi WPR framework explicitly, but their evidence and analysis clearly expose particular ways of thinking that led to lone parents being problematized and converted into targets for government scrutiny and punitive action. They reveal the discursive effects of categorising lone parents as a "problem» for public spending and public policy. Working backwards critically from that problem representation, they expose the silences within policy decisions that disregard the everyday lived effects experienced by women lone parents particularly, and how such a punitive representation of the "problem» imperils the economic and social wellbeing of lone parents and their children, the consequences of which redouble the need for welfare support. To this end, a «problem representation» of lone parents as a public finance problem, rather than a consequence of structural inequalities which could be remedied or at least reduced through provision of services that recognise care provision as the starting point for intervention, in the end runs counter to the new public management and reduction of welfare dependency discourse that shaped the representation of the problem.

Teasdale takes a familiar area of «gender» policy in her analysis of worklife balance policy and practice. The «reconciliation»' agenda has been a go-to area of gender equality policy at national and supra-national level for many years. Recasting gender relations in pursuit of a transformation of unpaid care and women's access to economic independence have been core missions of the feminist project. The institutionalisation of these demands as policy goals, however, has increasingly subjugated one form of knowledge for another as Teasdale's analysis reveals. 
Wilson and Campbell take on another established institutional gender equality policy in their analysis of gender mainstreaming in the European Structural and Investment Funds. Previously held up as a successful area of horizontal gender analysis and gender mainstreaming. The analysis of documentation shaping the 2014-2020 programmes in Scotland reveals a fading away of attention to gender analysis in programme design, monitoring and outcomes in Scotland. Furthermore, this highlights the importance of maintaining institutional structures that support gender analysis as Scotland reconfigured its programme management structures which had previously driven more gender aware programmes to international acclaim. Not only has gender analysis faded away in the nature of the programmes, but the pioneer state has become one of laggard, despite political rhetoric that aims to suggest otherwise. Wilson and Campbell locate the exploration of gender mainstreaming in the persistent subjugation of gender as relevant to economic development and infrastructure investment, drawing on feminist economics analysis to drive home the continuing undervaluing of women's economic participation. Their analysis also echoes Franzaway et al.'s characterisation of wilful ignorance within policy, and the need for collective, organisational responses and endeavours that Eveline and Bacchi have highlighted as essential to progress.

Steinpórsdóttir and Einarsdóttir's contribution on gender mainstreaming and gender budgeting in public institutions combines a critique of the evaporation of formal gender equality policy that echoes much of Wilson and Campbell's critique of Scotland. Both countries have enjoyed certain similarities of public perceptions as pioneers and leaders, particularly Iceland, whereas behind the «window dressing» commitments to gender budgeting and gender mainstreaming are still limited. Steinpórsdóttir and Einarsdóttir highlight the institutional practice to seek out or pursue «quick wins» -similar to Wilson and Campbell's identification of small scale advances- in both cases adopted in preference to the longer-term and, crucially, more disruptive process of thinking backwards that Bacchi exhorts. There is an unspoken resistance to reconsidering how public services might be differently constructed and delivered, based on a different engagement with what is the «problem» in the first place, and an understanding that it might not be what the institutional policy makers considered it to be in the first instance. 
This satisficing with small scale advances that Wilson and Campbell cite, is symptomatic of enduring institutional resistances around gender mainstreaming. For street-level bureaucrats in both the Icelandic and Scottish examples, the absence of clear direction through organisational hierarchies and the failure to transfer authority and seal in accountability for integrating gender analysis and advancing gender equality outcomes were common weaknesses.

The experience of the University of Iceland also has parallels with O'Hagan's article on using Bacchi's WPR framework as a pedagogic tool, supporting learning and building knowledge among policy makers in the third and public sector. Students in Iceland were encouraged to look behind the governmental practices that produced «problems», and to think otherwise about what the effects of policy might be on different needs across the population, and for service provision and policy intervention to use that understanding as a starting point.

Bacchi's wok over the last decades, urging a more discursive approach to lived realities, provides a highly useful framework for inquiry both to reveal absences of gender equality analysis and then try to explain them. Over the same time period from Bacchi's presentation of the original framework in 1999, multiple governments, national and international legal frameworks and policy commitments have extoled the virtues and necessity for public policy to be «gender aware» and to advance gender equality. These arguments have been framed in multiple ways, variously emphasising the moral imperative of gender equality as a social justice goal; as an essential principle of non-discrimination, central to the realisation of human rights; and as a matter of both economic justice from a feminist economics perspective, and of economic efficiency from a business case perspective. Gender equality therefore has been articulated as a common policy goal and political ambition shared at all levels of governance. Yet as the articles in this special issue reveal -but to no-one's great surprise- gender equality continues to be a constant and persistent absence from political aspiration and the policy processes that underpin the achievement of public policy goals.

Bacchi's critique of government policy making tells us that the focus on solving «problems» without understanding the underlying and background contexts and conditions, or reflecting upon the assumptions of policy 
makers themselves is deeply flawed. The «problem» then is how public policy approaches or «frames» a problem. It is the process of reflection of being aware and situated in the discursive and lived effects of everyday realties that shape people's lives that Bacchi and her colleagues have sought to open up through the refinements to the WPR approach and its application.

O'Hagan's article in this issue offers an example, at a very small scale, of how the training of policy makers to solve «problems» can be differently approached through the opportunity -and arguably responsibility- of critical management education. In designing coursework from a reflexive practice perspective with a pedagogy rooted in a social justice perspective and critical thinking, a different approach to policy making at organisational and governmental level might be possible. Higher education business schools do have choices to make in the curricula they offer and the theoretical foundations they promulgate. The business as usual model, however, continues to prevail, despite the evidence from many sources that the economic models of growth and rentier benefit have not served well the majority of the world's population. Bacchi is exhorting us as educators not to encourage students to solve problems, but rather to "generate critical thinking, not through training students to solve 'problems', but through encouraging them to put 'problems' into question».

As we have been writing this special issue and preparing for publication, the coronavirus has been sweeping across the world, with many of the contributors themselves being variously affected. The global pandemic of C-19 has exposed the underlying inequalities and structural inadequacies that have contributed to staggering imbalances in how it has been experienced at individual, household, sectoral and country levels. Over a decade of political choices to pursue austerity policies in relation to public spending and public infrastructure has left public services, supplies and workforces weakened and ill-prepared for a response at scale to a crisis such as this. Pre-existing social and economic inequalities that result in hunger and deprivation for many, even in the midst of "plenty» should shame the countries and societies where political choices -by voters and politicians- have permitted these «lived effects» to be the daily realities of millions.

The gendered dimensions of the impacts and experiences of C-19 and responses to treating and containing the virus have been evident from the 
outset. As the crises of gender inequality in all its intersectional dimensions have collided with coronavirus, the gender and racialized structures and the current economic and social systems that create them have been exposed to public view. As mainly women health and social care workers from a disproportionately high level of Black and minority ethnic communities provide care and die in the process and as lower income men die from occupational exposure to the virus, the gendered structures cannot be ignored.

The implications for policy makers of these imbalances, as countries move to economic and social renewal in a new paradigm of living with the virus are multiple. How public policy represents the challenge of funding a humane, dignified, rights-based social care system, or ensures a basic income that protects not only the most vulnerable, but the essential human vulnerabilities we all share, will require ways of «thinking otherwise» about public services and public spending. Will public resourcing continue to undercut labour and work-related supplies, producing situations like those we have witnessed in relation to the shortages of Personal Protective Equipment (PPE)? Will the low paid and unpaid domestic labour of women (mainly) continue to be acceptable in the service of the market and profit?

Antonella Picchio already forewarned us of how public resources have been weaponised against the resident populations of countries where social security and welfare systems have been dismantled (352). In this issue, Cohen and Samzelius have focused on the deliberate marginalisation and impoverishment of lone women parents within a representation of the 'problem' of lone parents as economically draining for the state, rather than the state having a duty of care to ensure basic freedoms and capabilities for all.

By reflecting, acknowledging, and ultimately discarding the assumptions that have hitherto shaped our economic and social structures we can collectively revisit how we represent «problems». In that way, we might come to a collective realisation that gender equality is not a policy to serve business interests, or to be instrumentalised as a lever for labour market expansion and an increase in the workforce, as Teasdale discusses in this issue. We may perhaps secure the political commitment to gender equality as a core and shared political goal that is for all times, and not only the «good times» when economies are «doing well». The alternative representation of the problem of gender «inequality» that requires resolution is as a fundamental human 
right and a cornerstone of future wellbeing and an axis of equality of rights, representation, and access to and benefits from resources that works for all.

In this issue, Ozonas' analysis of innovative approaches to budgeting in government finance that encompasses an original review of gender responsive budgeting (GRB), wellbeing budgeting (WBB), and wellbeing gender budgeting (WBGB) gives clear guidance on how to incorporate gender equality into the aspirations for economic and social wellbeing that are increasingly expressed by governments round the world. It is interesting to note, as an aside to Ozonas' contribution, that the small nations engaged in wellbeing budgeting include (at the time of writing) Iceland, New Zealand, Scotland (within the United Kingdom), and Finland, all have women leaders as heads of government. Just as this issue goes to print, the government of Wales -not headed by a woman, but recently re-committed to feminist principles of government and a roadmap for gender equality -has signed up to be a Wellbeing Economy government.

Setting aside the centrality or causal relationship between women heads of government and wellbeing policy making, despite the clear links, as the focus of a future special issue perhaps, it is also worth pausing for a moment to consider the scale and size of government and the pursuit of gender equality policies. Contributors in this volume have all presented examples of gender and public policy from small countries -some independent states such as Sweden, Iceland, Bhutan and New Zealand, and other autonomous sub-national governments, mainly Scotland within the United Kingdom. The size and scale of government is important in relation to its agility, and flexibility to respond to innovation- or crisis. The case studies on gender budgeting and gender mainstreaming in Bhutan and New Zealand, Iceland, and Scotland, and the comparison between the UK all demonstrate the importance of international policy learning and transfer, which has been a feature of how gender mainstreaming and gender budgeting have travelled. Part of the importance of this shared learning is the exchange of common experiences of what works well, and understanging the institutional resistances that appear to be as prevalent in Scotland as they are in Iceland or New Zealand, whatever the superficial perception of a country's status as a gender equality champion. Perhaps there is a different humility with small nations towards learning from others. While still endowed with their own sense of self and natural arrogance of state, there 
is a willingness to learn and share. Such speculation is appropriate as we seek a shared response to the global coronavirus pandemic and the lessons that must be learned from it and the inequalities it so ruthlessly exposed.

That this small special issue has been able to include such a range of country perspectives is a source of great pride and pleasure. Feminismo/s is an international journal of increasing standing and reach. The importance of comparative analysis and shared learning has characterised this special issue. As the guest editor of this volume, I am immensely indebted to the authors and contributors, for some of whom this is their first publication and so they deserve special congratulations. The collaboration and enthusiasm with which the contributors have engaged have been immense and inspiring, and I am very grateful to all the authors for their commitment and hard work. The many reviewers who supported the process of producing this special issue have provided an academic and scholarly rigour to the process, and their contributions have significantly elevated and enhanced the authors' contributions. I appreciate the time the reviewers gave, especially when there are so many demands on academic researchers and teachers, and the diligence with this they conducted the evaluations. My biggest vote of thanks is, of course, reserved for the Editor and editorial team who have worked so very hard to support the special issue and to secure its timely publication to the best standards possible. My most sincere thanks and appreciation to you all. And to our readers, I hope we have offered knowledge, exposed silences, and further encouraged you in your «critical practice of thinking otherwise».

Angela O'Hagan, June 2020

\section{REFERENCES}

Bacchi, Carol. Analysing Policy: What's the Problem Represented to be? Frenchs Forest, NSW: Pearson Education. 2009.

Bacchi, Carol, and Joan Eveline. «Approaches to gender mainstreaming: What's the problem represented to be?». In Mainstreaming politics: Gendering practices and feminist theory. Eds. Carol Bacchi and Joan Eveline. Adelaide: University of Adelaide Press, 2010. 111-138.

Bacchi, Carol, and Joan Eveline. "What are we mainstreaming when we mainstream gender?». In Mainstreaming politics: Gendering practices and feminist 
theory. Eds. Carol Bacchi and Joan Eveline. Adelaide: University of Adelaide Press, 2010. 87-110.

Bacchi, Carol, and Susan Goodwin. Poststructural policy analysis: A guide to practice. New York: Springer, 2016.

Bunch, Charlotte. «Women's rights as human rights: Toward a re-vision of human rights», Human Rights Quarterly 12. 4 (1990): 486-498.

Bustelo, María. «Evaluation from a gender+ perspective as a key element for (re) gendering the policymaking process.» Journal of Women, Politics \& Policy 38. 1 (2017): 84-101.

Eveline Joan, and Carol Bacchi. «Obeying organizational 'rules of relevance': gender analysis of policy». In Mainstreaming politics: Gendering practices and feminist theory. Eds. Carol Bacchi and Joan Eveline. Adelaide: University of Adelaide Press, 2010. 283-310

Franzway, Suzanne, Rhonda Sharp, Julie E. Mills, and Judith Gill. «Engineering ignorance: The problem of gender equity in engineering». Frontiers: A Journal of Women Studies 30. 1 (2009): 89-106.

Goodwin, Susan, and Archana Preeti Voola. «Framing microfinance in Australia-gender neutral or gender blind?». Australian Journal of Social Issues 48. 2 (2013): 223-239.

Mukhopadhyay, Maitrayee. «Mainstreaming gender or reconstituting the mainstream? Gender knowledge in development». Journal of International Development 26.3 (2014): 356-367.

O'Hagan, Angela. «Conceptual and Institutional Origins of Gender Budgeting». In Gender Budgeting in Europe: Developments and Progress. Eds. Angela O'Hagan and Elisabeth Klatzer. New York, London: Palgrave Macmillan, 2018. 19-42.

Picchio, Antonella. «Reflections on the Politics and Context of Gender Budgets: A Feminist Perspective». In Gender Budgeting in Europe: Developments and Progress. Eds. Angela O'Hagan and Elisabeth Klatzer. New York, London: Palgrave Macmillan, 2018. 345-360. 